\title{
A review of the current digestate distribution models: storage and transport
}

\author{
P. Vilanova Plana \& B. Noche \\ Faculty of Engineering, Transport Systems and Logistics, \\ University of Duisburg-Essen, Germany
}

\begin{abstract}
Over the past few years, the biogas sector has experienced an important growth in the number of biogas installations all over Europe, and consequently, the quantity of digestate also has had a significant increase. In Europe, biogas production by anaerobic digestion $(\mathrm{AD})$ is a common source of renewable energy and the current amount of installations is around 13,000. Together with biogas, digestate is one of the two main by products resulting from the biogas process. The digested effluent is a liquid product rich in nitrogen $(\mathrm{N})$, phosphorus $(\mathrm{P})$, potassium $(\mathrm{K})$ and micronutrients. Therefore, there is a wide variety of digestate utilization depending on the quality, the origin of the feedstock, the operating conditions of the process as well as the phase of the by-product. The most common end uses are biofertilizer and soil amendment, due to its essential characteristics and when the quality is adequate for agriculture use. Before land application, environmental and agronomic reasons affect the storage of the digestate for a required period of time, in the biogas installations or near the area of application. Hence, the increasing production of digestate, the low solids content of whole digestate and the vulnerability of several land areas to the amount of nitrate and phosphate in Europe, convert the biofertilizer into a bottleneck for the biogas sector, due to the difficulty for its management.

This paper contains an extensive review of the technical literature regarding digestate distribution. The objectives of this paper were to identify and analyse the current digestate distribution systems; storage and transport in Europe.

Keywords: digestate, digestate distribution, storage, transport.
\end{abstract}




\section{Introduction}

Biogas production by anaerobic digestion (AD) is a common source of renewable energy. Biogas energy may have several benefits; it reduces pollution from agricultural and industrial activities, generates green energy reducing the usage of fossil fuels, and also permits the production of biofertilizer, decreasing the utilization of mineral fertilizers. In Europe, the number of biogas installations reached in 2013, 13378.7 units and the biogas primary energy produced was 13.4 Mtoe [1]. Biogas can be produced in different installations such as anaerobic digesters, wastewater treatment plants or landfills sites. Consequently, and as a result of the $\mathrm{AD}$, two valuable products are produced; biogas and digestate. Biogas is a gaseous fuel that can be burnt directly to produce electricity and heat [2], used as a transport fuel, or purified for injection into the gas grid, and digestate is a highly valuable biofertilizer [3], rich in both organic matter and in macro- and micronutrients. There is a wide variety of digestate utilization depending on the quality, the origin of the feedstock, the operating conditions of the process as well as the type of digestate. Although it is considerate a high quality biofertilizer, other uses have been proved, in different studies, such as a soil amendment [4] or soil fuel [5].

The increasing number of biogas installations involves an increase in the amount of digestate that is obtained. Thus, an average of approximately 20 cubic meters of digestate can be produced per year and kilowatt of installed electric capacity. An average biogas plant using renewable raw materials with a capacity of $500 \mathrm{~kW}_{\text {el }}$ produces about 10.000 tons of digestate per year [6]. Moreover, digestate usually has low dry matter content and low nutrient concentration. For these reasons its storage, transport and application are expensive [7].

The aim of the present paper is to provide information concerning the current distribution models for digestate. The technical information used for the implementation of the paper was resulting and based on peer-reviewed scientific literature and technical reports with relation to current digestate distribution models.

\section{Background and objectives of digestate distribution models}

Management of digestate involves several topics such as storage, processing, transportation, utilization, economics, and environmental quality.

Digestate has high water content and consequently high volume compared to its fertilizer value, so it requires large amount of space for storage facilities at the biogas installation or close to the area of utilization. Before the utilization of digestate, it is stored and several factors affect the required storage period, such as environmental restrictions for application, digestate stabilization, geographical location, soil and crop type, and digestate demand. The storage of digestate entails a significant cost for the biogas system, as well as occupation of land, for example a biogas installation of $500 \mathrm{~kW}$ requires 4 ha for storage facility [8].

Mostly, the treatment of digestate aims to reduce volume and concentrate nutrients. Partial processing will reduce the volume of the digestate, for example 
through solid- liquid separation of the whole digestate, and complete processing will recover nutrients $(\mathrm{N}, \mathrm{P}, \mathrm{K})$, so some technologies are available today at the market such as composting, drying, evaporation, ammonia stripping, and membrane separation. The cost of installation and operation of several of those techniques are high, due to adequate machinery, high energy consumption and reagent consumption.

On the other hand, and regarding digestate transportation, the cost of transportation is a critical factor for the viability of biogas plant, due to the water content of the digestate, thus the efforts to minimize the cost of the logistics of digestate are essentials to be able to make more profitable the product and the biogas sector.

The quality of digestate defines the possible end-use. The main practice is land application due to the characteristics of the effluent of $\mathrm{AD}$, because it is rich in nitrogen, phosphate and potassium, but on the other hand it may content some heavy metals [9], antibiotics [10], organic pollutants [11] or pathogens that can limit digestate utilization [12]. In many parts of Europe, livestock production is concentrated and intensive, and creates a permanent excess of nutrients, making such areas highly vulnerable from the point of view of nutrient pollution of ground and surface waters [13]. The amount of ammonium-nitrogen contented in digestate limits the use of digestate due to environmental regulations which control the environmental risk regarding nitrates, where the maximum amount of nitrogen that can be supplied to the land is $170 \mathrm{~kg} \mathrm{~N} / \mathrm{ha} /$ year, and it is regulated by the council directive of 12 December 1991 concerning the protection of waters against pollution caused by nitrates from agricultural sources (91/676/EEC). The required storage capacity and the compulsory season for spreading in different countries in Europe, that it is related to the quality of digestate (as shown in table 1). Furthermore, phosphorus contented in digestate affects the quality of surface and ground waters, and it also limits the use of the anaerobic digestate for fertilizing proposes. Phosphorus, which is responsible for eutrophication, has also to be considered in the digestate management and it is regulated by the European directive of Water Framework Directive (2000/60/EC, WFD). In addition, environmental regulations regarding heavy metals also apply to the digestate quality, it has been regulated since June 1986 by the European directive $86 / 278 /$ EEC on the protection of the environment, and in particular on the soil, when sewage sludge is used in agriculture. Furthermore, in some countries there are national and local regulations regarding the environmental parameters and also the agronomical ones are defined in order to limit the use to sewage sludge with a high organic matter content and good level of nutrients. Pathogens are controlled by the Regulation (EC) No 1069/2009 of the European parliament and of the council of 21 October 2009 laying down health rules as regards animal byproducts and derived products not intended for human consumption and repealing Regulation (EC) No 1774/2002 (Animal by-products Regulation).

For these reasons, some European countries have developed standards for the regulation on digestate; Germany (RAL GZ 245 Digestate from biowaste, RAL GZ 246 Digestate from energy crops), Sweden (SPCR 120 Biowaste digestion residues) or United Kingdom (PAS 110) for example. 
Table 1: Examples of national limits regulating nitrogen loading on farmland, required storage capacity for digestate, and its spreading season [14].

\begin{tabular}{|c|c|c|c|}
\hline COUNTRY & $\begin{array}{c}\text { MAXIMUM NUTRIENT } \\
\text { LOAD }\end{array}$ & $\begin{array}{c}\text { REQUIRED } \\
\text { STORAGE } \\
\text { CAPACITY }\end{array}$ & $\begin{array}{c}\text { COMPULSORY } \\
\text { SEASON FOR } \\
\text { SPREADING }\end{array}$ \\
\hline Austria & $170 \mathrm{~kg} \mathrm{~N} / \mathrm{ha} /$ year & 6 months & $28 / 02-25 / 10$ \\
\hline Denmark & $\begin{array}{c}170 \mathrm{~kg} \mathrm{~N} / \mathrm{ha} / \text { year }(\text { cattle }) \\
140 \mathrm{~kg} \mathrm{~N} / \mathrm{ha} / \text { year }(\mathrm{pig})\end{array}$ & 9 months & $1 / 2-$ harvest \\
\hline Italy & $170-500 \mathrm{~kg} \mathrm{~N} / \mathrm{ha} /$ year & $90-180$ days & $1 / 2-1 / 12$ \\
\hline Sweden & $\begin{array}{c}170 \mathrm{~kg} \mathrm{~N} / \mathrm{ha} / \text { year }(\text { calculated } \\
\text { from livestock units per ha) }\end{array}$ & $6-10$ months & $1 / 2-1 / 12$ \\
\hline Northern Ireland & $170 \mathrm{~kg} \mathrm{~N} / \mathrm{ha} /$ year & 4 months & $1 / 2-14 / 10$ \\
\hline Germany & $170 \mathrm{~kg} \mathrm{~N} / \mathrm{ha} /$ year & 6 months & $\begin{array}{c}1 / 2-30 / 10 \text { Arable land } \\
1 / 2-14 / 11 \text { Grassland }\end{array}$ \\
\hline
\end{tabular}

Hence, the main objective of digestate distribution models is to optimize the management of the digestate, from an environmental and economical perspective, to guarantee the viability of the biogas system.

\section{Digestate}

\subsection{Digestate characteristics}

Digestate is the liquid-solid by-product produced through the $\mathrm{AD}$ of organic material. The anaerobic effluent contains macronutrients (N, P, K, Ca, S and $\mathrm{Mg}$ ) and micronutrients ( $\mathrm{B}, \mathrm{Cl}, \mathrm{Mn}, \mathrm{Fe}, \mathrm{Zn}, \mathrm{Cu}, \mathrm{Mo}$ and $\mathrm{Ni}$ ). Usually, its characteristics depend on the input material, operating conditions of the AD process and digestate processing techniques. The nutrient composition of the feedstock affects the biogas composition and specific methane yield, as well as the composition of the digestate [2]. The substrates commonly used in AD include manure, agricultural waste, energy crops, waste from food-processing industries, sewage sludge and organic municipal waste [15]. Depending on the AD process and the feedstock, the dry solids content can vary in a considerable wide range of about 3.5 to $13 \%$ [6].

In general, the anaerobic digestate is rich in nitrogen $(\mathrm{N})$, phosphorous $(\mathrm{P})$ and potassium (K). After solid-liquid separation the liquid part contains high $\mathrm{N}$ percentage and the solid part contains high $\mathrm{P}$ content. In addition, the presence of heavy metals $(\mathrm{Cd}, \mathrm{Cr}, \mathrm{Pb}, \mathrm{Ni}, \mathrm{Hg}, \mathrm{Cu}, \mathrm{Zn})$ and organic pollutants can be found [16].

Table 2 shows some of the characteristics of the digestate.

\subsection{Types of digestate}

Digestate, based on its physical properties, can be classified as whole digestate, liquid fraction or liquor, and solid fraction or cake, and their characteristics rely basically on the solid-liquid separation technique applied.

On the other hand, digestate can also be classify, depending on the source of feedstock, such as agriculture-based digestate (manure and crops), digestate from food and municipal waste, and digestate from waste water treatment plant. 
Table 2: Digestate characteristics [12].

\begin{tabular}{|l|c|c|}
\hline & ABSOLUTE VALUES & CHANGE ${ }^{\text {) }}$ \\
\hline DM (\%) & $1.5-13.2$ & -1.5 to -5.5 \\
\hline Organic DM (\%DM) & $63.8-75.0$ & -5 to -15 \\
\hline Total N (\%DM) & $3.1-14.0 \%$ & b) \\
\hline Total N (kg Mg -1 FM) & $1.2-9.10$ & $\approx 0$ \\
\hline Total $\mathrm{NH}_{4}{ }^{+}(\mathrm{kg} \mathrm{Mg} \mathrm{-1} \mathrm{FM)}$ & $1.5-6.8$ & $?$ \\
\hline $\mathrm{NH}_{4}{ }^{+}$share on total N (\%) & $44-81 \%$ & +10 to +33 \\
\hline Total C content (\%DM) & $36.0-45.0$ & -2 to -3 \\
\hline C:N ratio & $3.0-8.5$ & -3 to -5 \\
\hline Total P content (\%DM) & $0.6-1.7$ & b) \\
\hline Total P (kg Mg -1 FM) & $0.4-2.6$ & $\approx 0$ \\
\hline Water soluble P (\% of total P) & $25-45$ & -20 to -47 \\
\hline Total K (\%DM) & $1.9-4.3$ & b) \\
\hline Total K (kg Mg-1 FM) & $1.2-11.5$ & $\approx 0$ \\
\hline Total Mg (kg Mg-1 FM) & $0.3-0.7$ & $\approx 0$ \\
\hline Total Ca (kg Mg-1 FM) & $1.0-2.3$ & $\approx 0$ \\
\hline Total S (kg Mg-1 FM) & $0.2-0.4$ & $?$ \\
\hline pH & $7.3-9.0$ & +0.5 to +2 units \\
\hline
\end{tabular}

a) In comparison to undigested liquid animal manures, absolute values.

b) Increases with degree of DM degradation.

$\mathrm{DM}=$ Dry matter. $\mathrm{FM}=$ Fresh matter. $?=$ No data found/no data available.

Table 3: $\quad$ Substrate parameters influencing digestate composition [12].

\begin{tabular}{|c|c|}
\hline SUBSTRATE PARAMETER & IMPACT ON DIGESTATE COMPOSITION \\
\hline Organic waste & $\begin{array}{l}- \text { low total solids (TS) content } \\
\text { - low percentage of organics in TS }\end{array}$ \\
\hline High amount of abattoir waste & $\begin{array}{l}\text { - high nitrogen concentration } \\
\text { - high percentage of ammonia in total nitrogen }\end{array}$ \\
\hline High amount of manure & $\begin{array}{l}\text { - low total solids (TS) content } \\
\text { - considerable nitrogen concentration }\end{array}$ \\
\hline Energy crops & $\begin{array}{l}- \text { high total solids (TS) content } \\
\text { - high percentage of organics in TS (VS/TS ratio) }\end{array}$ \\
\hline
\end{tabular}

\subsection{Use of the digestate}

There is a wide range for utilization of digestate, which depends on the quality and the origin of the input substrate, as well as the type and characteristics of digestate. The most common use is land application such as fertilizer and soil conditioner [4], only if heavy metal content ( $\mathrm{Cd}, \mathrm{Cr}, \mathrm{Pb}, \mathrm{Ni}, \mathrm{Hg}, \mathrm{Cu}, \mathrm{Zn}$ ) and organic pollutants make it suitable for agriculture use. 
Moreover, digestate can also be converted into compost [17], used for growing medium for plants and for land regeneration. Other studies proved uses such as solid fuel such as a promising alternative after its drying and pelletizing [5]. Digestate can also be used as building material. In addition, after separation of the digestate, the liquid phase may have different end-uses. It can be spread directly to the land as N-rich fertilizer, or recirculated to the AD process as process water, or further treated to obtain concentrates or pure water [18].

\section{Parameters for digestate logistics}

The influence of the logistics in the feasibility of the biogas systems is quite important due to its high cost. A proper management of the digestate will guarantee a reduced cost of the overall economics of the biogas system. Several parameters influence the logistics for the digestate:

- Digestate treatment;

- Storage installations and demand;

- Transportation modes and distances;

- Biogas plant location and place of digestate utilization;

- Digestate utilization and application.

\section{Digestate processing}

Digestate processing technologies can play an important role in the management of digestate by providing water reduction, nutrient management, proper storage, or/and enhance quality. The installation of a digestate processing technology is due to the impossibility of spreading digestate near the biogas plant, and consequently digestate have be to be transported longer distances for its disposal. Nowadays several treatment technologies are being used at the biogas sector, and the selection of the suitable technology will highly depend on the digestate characteristics, location, local conditions, energy requirements, chemical addition requirements, end- user and investment cost. The water content of the digestate has a decisive influence on the costs of the treatment of digestate [19]. Digestate processing is not a standard or defined process, it depends on the requirements of a specific biogas installation, local conditions and applicable regulations, and it can consist of a single process or a combination of several techniques. Moreover, digestate processing can be partial, primarily for the purpose of volume reduction, or it can be complete, refining digestate to pure water, a solid biofertilizer fraction, and fertilizer concentrates [20]. Partial treatment is less energy demanding, cheaper and, in regions where there is a surplus of phosphorus, it is the most economical conditioning technology [21]. A partial treatment is the solid-liquid separation process, and it is usually the first step in the digestate processing, which divides the digestate into a concentrated phosphorus rich solid phase and a nitrogen rich fluid phase, and it aims to dewater the digestate, and allows handling nutrients separately [22]. Thus solid-liquid separation provides a lower transport cost [23], due to the reduced water content, as well as simpler storage conditions [18]. 
In addition, other technologies are available at the market, which main to recover nutrients $(\mathrm{N}, \mathrm{P}, \mathrm{K})$ such as composting, drying, ammonia stripping, evaporation, and membrane filtration technologies. Generally, these technologies entail high investment cost, huge energy requirement, high maintenance cost, and large amount of chemical reagents [7]. For this reason, they are economically feasible for biogas plants with capacities higher than $700 \mathrm{~kW}$ [12].

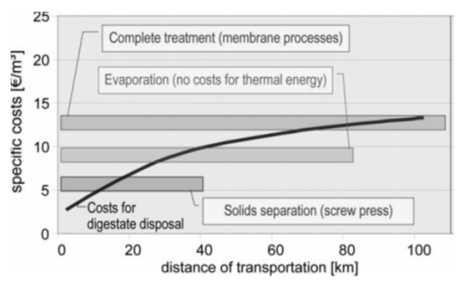

Figure 1: Comparison of cost ranges for specific treatment options versus costs for digestate disposal [18].

\section{Digestate storage}

Digestate, which is generated continually through the AD process, has to be stored properly until the growing season or vegetative growth, which is the only appropriate time for its application as a fertilizer, due to crop nutrient requirements and to avoid nutrient losses. Hence, biogas plants must have proper facilities with the required storage capacity, or in an alternative case, digestate could be transported and stored in a headland tank on field close to the destination point. In case the storage facility is located in the biogas installations, a storage facility for a $500 \mathrm{~kW}_{\mathrm{el}}$ biogas plant may need around 4 ha of dedicated space [7].

The storage systems have to be designed based on digestate production volumes, digestate type, digestate demand, land availability, crop type, geographical area, soil type and environmental restrictions. The volume of digestate, which is produced during the processes, depends on the input material and the frequency with which the digestate storage facilities are emptied. Reference values for the mass loss of the input substrate related with the digestate that is obtained are 3\% for manure and 20 to $30 \%$ for silage, and for cereal grains, 70 to $80 \%$ mass loss may be expected [6]. The type of digestate also impacts on the storage facility, whole digestate and liquid fraction of digestate are usually stored in storage tanks, lagoons or flexible storage bags, and on the other hand solid fraction of digestate is stored in covered flat concrete areas or inside buildings. Finally, and depending on the crop, the best time for digestate application generally is during growing season, to avoid nutrient leaching and runoff into ground water. For this reason, European legislations demand a storage capacity for 6 to 9 months, due to seasonal variations [24].

In addition, digestate storage facilities must be built with materials and characteristics that guarantee the water tightness, to avoid water and soil pollution. In some countries several environmental measures may also be required such as spillage, waterproof liners, and leakage detector to be place at the storage facility. 
Furthermore, during the storage period some emissions may occur, if digestate is stored in open tanks, and the emissions rely on the $\mathrm{pH}$, temperature, dry matter content, nitrogen content and storage characteristics of the digestate. An effective method for minimizing emissions is the installation of air tight storage covers, which allow reducing the gaseous emissions $\left(\mathrm{CH}_{4}, \mathrm{~N}_{2} \mathrm{O}, \mathrm{NH}_{3}\right)$ by $90 \%$, and 55 $100 \%$ of $\mathrm{NH}_{4}-\mathrm{N}$ retained in the digestate [25]. Another advantage of installing storage covers is that, they also avoid the accumulation of rain water, and consequently the dilution of the digestate and the increment of the volume. The cover material of the storage facility can be a membrane, concrete, steel or a floating cover of straw, clay granules or plastic on top of the liquid surface [26]. Basically, proper storage preserves value and qualities of digestate, and prevents losses of ammonia and methane to the atmosphere, nutrient leakage and nutrient run off, as well as emissions of odors and aerosols [27]. Basically, covered digestate storage decreased the emissions from digestate storage tank by $65 \%$ as opposed to open storage [28].

The most common storage systems are lagoons, storage tanks, and flexible storage bags. Lagoons are outdoor pits or ponds. Generally, lagoons are deep pits, with a sealed bottom and sides which allows to storage digestate, and a waterproof membrane or layer is installed, for protection proposes. Polyvinyl chloride (PVC) membranes or concrete are the adequate waterproof component to avoid leaching. Furthermore, the size of a lagoon is based on the volume of the total digestate entering into the lagoon, and precipitation and runoff volumes. They can be built above or below ground, whereby below ground lagoons are not visible from outside, and consequently the landscape impact is therefore minimal. Besides, lagoons can be covered or uncovered, with flexible covers. Covered lagoons offer significant environmental benefits reducing ammonia loss, methane emissions and odor, as well as it avoids the increment of water content in digestate due to rain water. An important consideration is that earth settlement or even earthquakes cannot damage lagoons easily unlike any other digestate storage due to the construction materials. An alternative to lagoons may be storage tanks, which can be built partly above ground or buried in the ground. The first option may prove cheaper to construct than tanks buried in the ground, but digestate would need to be pumped to aboveground stores [29]. Storage tanks can be built with different materials such as concrete or steel. Poured concrete can be designed with cylindrical shape on site, and precast concrete panels that are formed at an off-site factory can be transported and tipped up vertically on site. Steel is another option as building material for storage tanks, which can be erected either as bolted together panels or as welded steel panels. Furthermore, steel can be stainless steel or coated with an epoxy paint system or with a glass-fused-to-steel coating. Steel tanks can be joined to the concrete foundation by means of an embedded ring cast into the tank foundation. Depending on the country, the storage installations must have a synthetic liner to avoid leaching as a preventive environmental measure. Finally, flexible storage bags are air-tight facilities used to storage digestate. They are built several meters below ground as the storage tanks and the material which they are built is PVC-coated polyester fiber with high tensile strength. Mostly, another component is installed in the storage facilities, and it is mixing system 
which avoids sedimentation and reduction of the capacity of the storage facility, as well as it gives homogeneity to the digestate before use and. The facilities analyzed before aims to storage the liquid fraction of the digestate or the whole digestate, so regarding the solid phase it is stored in covered flat areas or buildings with a slight floor slope to recollect the leachate.

\section{Transportation modes}

Once digestate is generated and stored, it has to be transported to the destination point. The transportation of digestate is an important cost of the overall biogas production economics, due to the high water content of the digestate [30]. Figure 2 shows the relation between the costs of digestate related with the distance to be transported. So, digestate processing has an important impact on the cost of transport, when they aim to reduce water content recover nutrients of the digestate. However, the high water content leads to comparatively high costs for transport and spreading of the digestate. For example, the transport cost can be reduced by separating the manure into a nutrient-rich solid fraction and a liquid fraction [22].

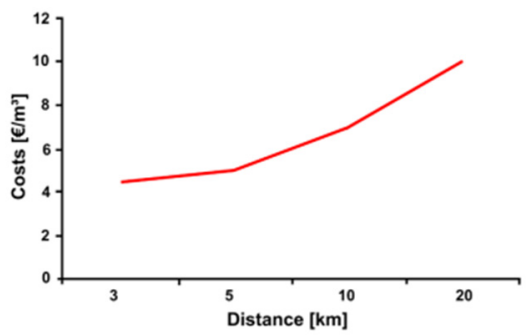

Figure 2: Relation between distance and cost of digestate transportation [2].

The mode of transport varies depending on the distance to the place of utilization, the type of digestate, and digestate processing. The most usual modes of transport are tractors, dumpers, trucks, bulk transport, and pipelines. Nowadays, the most common form of digestate transportation is by truck [31]. The following table shows the most common modes of transport used for digestate transportation, and the estimation on the transport cost depending on the type of vehicle and its capacity.

Pipeline transport of digestate can be considered as an alternative way for the transportation of digestate [31]. Pipelining of biomass has a significant economy of scale, with a scale factor less than 0.5 whereas truck transport has no economy of scale: more material simply requires more truck trips, with no or very minor variation in unit cost of transport [33]. But on the other hand, pipelines are also beneficial for large scale transport over longer distances [34]. In case the selection of the transport mode is by pipelines it is important to consider the digestate processing technics to be applied as dilution increases and solids concentration drops, the viscosity of the digestate is reduced, giving lower pumping costs. More dilute digestate require a larger diameter pipeline, requiring additional capital investment [34]. 
Table 4: Estimating transport costs, depending on the type of vehicle and its capacity [32].

\begin{tabular}{|c|c|c|c|c|}
\hline MODE & $\begin{array}{c}\text { CAPACITY } \\
\left(\mathbf{m}^{3}\right)\end{array}$ & $\begin{array}{c}\text { CONSUMPTION } \\
\text { (Diesel/h) }\end{array}$ & $\begin{array}{c}\text { POWER } \\
\text { (CV) }\end{array}$ & $\operatorname{Cost}(€ / h)$ \\
\hline \multirow{3}{*}{ Dumper } & 20 & 15 & 320 & 31.9 \\
\hline & 25 & 16 & 375 & 34.0 \\
\hline & 30 & 17 & 400 & 36.9 \\
\hline \multirow{3}{*}{$\begin{array}{c}\text { Truck with } \\
\text { trailer }\end{array}$} & 16 & 15 & 320 & 30.2 \\
\hline & 22 & 16 & 375 & 32.3 \\
\hline & 27 & 17 & 400 & 35.1 \\
\hline Tractor & 16 & 16,8 & 140 & 26.9 \\
\hline
\end{tabular}

\section{Distribution models}

Nowadays different distributions models are applied depending on the specific biogas installation, geographical area, type of feedstock and digestate, and economics. Digestate distribution models are not a standard method which can be useful for all the biogas plants, and bad choices about how digestate is distributed can be critical to the viability of an AD project. Hence, it is important to analyse the characteristics of each biogas installation to develop a proper digestate management plan which should be integrated in the fertilizing plan of the farm in the same way as mineral fertilizers and it must be applied at even and accurate rates [27].

The most common distribution models are:

Option 1: Whole digestate is stored in a digestate storage tank for a time period and then transported to farmlands by trucks and spread on farmlands using conventional methods for spreading liquid manure [18]. The AD company will be the responsible of the digestate management.

Option 2: Whole digestate, after its storage, is pumped and translated through buried pipelines to land fields and spread it on land by methods for spreading liquid manure. The AD company will be the responsible of the digestate management.

Option 3: Digestate after partial processing (solid-liquid separation) will be handling different depending on the phase. Solid fraction can be applied directly to land by the AD company, or it can be dried or composted. The processing of the solid fraction can be managed by the AD company if the required installations are in the biogas installations, or it can be managed by another company. On the other hand, liquid digestate can be recirculated to the process or transported and spread it to the land, by the AD company, or it can be further processed. Mostly, the processing of the liquid fraction is realized by another company or a waste water plant.

Option 4: The AD company produce digestate which is managed by a company that is the responsible of the transport and application of the digestate. Frequently, such companies are in charge of the feedstock supply as well. 
Option 5: The AD company treat livestock from different farms, and the owners of the farms are in charge of the supply of the feedstock as well as the return of the digestate to the lands.

\section{References}

[1] EurObserv 'ER, Baromètre biogaz Biogas barometer. [Online] Available: $\mathrm{http}: / /$ www.eurobserv-er.org/category/all-biogas-barometers/.

[2] P. Weiland, "Biogas production: current state and perspectives," Applied microbiology and biotechnology, vol. 85, no. 4, pp. 849-860, 2010.

[3] C. T. Lukehurst, P. Frost, and T. Al Seadi, "Utilisation of digestate from biogas plants as biofertiliser,"

[4] F. Tambone, P. Genevini, G. D'Imporzano, and F. Adani, "Assessing amendment properties of digestate by studying the organic matter composition and the degree of biological stability during the anaerobic digestion of the organic fraction of MSW," Bioresource technology, vol. 100 , no. 12 , pp. 3140-3142, 2009.

[5] M. Kratzeisen, N. Starcevic, M. Martinov, C. Maurer, and J. Müller, "Applicability of biogas digestate as solid fuel," Fuel, vol. 89, no. 9, pp. 2544-2548, 2010.

[6] F. Wäger-Baumann, Physical and biological methods for the treatment of the liquid fraction of anaerobic digester effluent: na, 2011.

[7] A. Wellinger, J. D. Murphy, and D. Baxter, The biogas handbook: science, production and applications: Elsevier, 2013.

[8] R. C. Brändli et al., "Persistent organic pollutants in source-separated compost and its feedstock materials - a review of field studies," Journal of environmental quality, vol. 34, no. 3, pp. 735-760, 2005.

[9] T. Kupper, D. Bürge, H. J. Bachmann, S. Güsewell, and J. Mayer, "Heavy metals in source-separated compost and digestates," Waste Management, vol. 34, no. 5, pp. 867-874, 2014.

[10] A. Spielmeyer, J. Ahlborn, and G. Hamscher, "Simultaneous determination of 14 sulfonamides and tetracyclines in biogas plants by liquid-liquidextraction and liquid chromatography tandem mass spectrometry," Analytical and bioanalytical chemistry, vol. 406, no. 11, pp. 2513-2524, 2014.

[11] E. Govasmark et al., "Chemical and microbiological hazards associated with recycling of anaerobic digested residue intended for agricultural use," Waste Management, vol. 31, no. 12, pp. 2577-2583, 2011.

[12] B. Drosg, W. Fuchs, T. Al Seadi, M. Madsen, and B. Linke, Nutrient Recovery by Biogas Digestate Processing," IEA Bioenergy. Accessed on: Apr. 202016.

[13] T. Al Seadi, Good Practice in Quality Management of AD residues from biogas production.

[14] K. Möller and T. Müller, "Effects of anaerobic digestion on digestate nutrient availability and crop growth: a review," Engineering in Life Sciences, vol. 12, no. 3, pp. 242-257, 2012. 
[15] L. Appels et al., "Anaerobic digestion in global bio-energy production: potential and research challenges," Renewable and Sustainable Energy Reviews, vol. 15, no. 9, pp. 4295-4301, 2011.

[16] M.-L. Nilsson, H. Kylin, and P. Sundin, "Major extractable organic compounds in the biologically degradable fraction of fresh, composted and anaerobically digested household waste," Acta Agriculturae Scandinavica, Section B-Plant Soil Science, vol. 50, no. 2, pp. 57-65, 2000.

[17] M. A. Bustamante et al., "Recycling of anaerobic digestates by composting: effect of the bulking agent used," Journal of Cleaner Production, vol. 47, pp. 61-69, 2013.

[18] W. Fuchs and B. Drosg, "Assessment of the state of the art of technologies for the processing of digestate residue from anaerobic digesters," Water Science \& Technology, vol. 67, no. 9, 2013.

[19] Bioenergy association of New Zeland, "The production and use of digestate as fertiliser," Bioenergy association of New Zeland, 2013. [Online] Available:http://www.bioenergy.org.nz/documents/resource/TG08-theproduction-and-use-of-digestate-as-fertiliser.pdf.

[20] B. Drosg, W. Fuchs, T. Al Seadi, M. Madsen, and B. Linke, "Nutrient Recovery by Biogas Digestate Processing," IEA Bioenergy, 2015.

[21] M. Dumitru, "Studies concerning the utilisation of digestate in biogas plants," Studies, vol. 14, no. 1, 2014.

[22] H. B. Møller, I. Lund, and S. G. Sommer, "Solid-liquid separation of livestock slurry: efficiency and cost," Bioresource technology, vol. 74, no. 3, pp. 223-229, 2000.

[23] A. Bauer, H. Mayr, K. Hopfner-Sixt, and T. Amon, "Detailed monitoring of two biogas plants and mechanical solid-liquid separation of fermentation residues," Journal of biotechnology, vol. 142, no. 1, pp. 56-63, 2009.

[24] Al Seadi, T, Rutz, D, Prassl, H, Köttner, M. \& Finsterwalder, T, Biogas handbook: University of Southern Denmark Esbjerg, 2008.

[25] T. Rehl and J. Müller, "Life cycle assessment of biogas digestate processing technologies," Resources, Conservation and Recycling, vol. 56, no. 1, pp. 92-104, 2011.

[26] R. Nicolai, S. H. Pohl, and D. Schmidt, Covers for manure storage units.

[27] Al Seadi, T, \& Lukehurst, C, Quality management of digestate from biogas plants used as fertiliser.

[28] S. Luostarinen, A. Normak, and M. Edström, "Overview of biogas technology," 2011.

[29] Guidelines for Sustainable Manure Management in Asian Livestock Production Systems: International Atomic Energy Agency. IAEA, Publications, Sales and Promotion Unit, 2008.

[30] S. A. Gebrezgabher, M. P. M. Meuwissen, B. Am Prins, and A. G. O. Lansink, "Economic analysis of anaerobic digestion-A case of Green power biogas plant in The Netherlands," NJAS-Wageningen Journal of Life Sciences, vol. 57, no. 2, pp. 109-115, 2010. 
[31] E. Ghafoori, P. C. Flynn, and J. J. Feddes, "Pipeline vs. truck transport of beef cattle manure," Biomass and Bioenergy, vol. 31, no. 2, pp. 168-175, 2007.

[32] E. Campos, J. Palatsi, J. Illa, F. Sole, A. Magri, X. Flotats, "Guia de tratamiento de las deyecciones ganaderas," Generalitat de Catalunya, 2004. [Online] Available: http://residus.gencat.cat/web/.content/home/ambits dactuacio/tipus_de_residu/dejeccions_ramaderes/guia_de_tractaments_de les_dejeccions_ramaderes/guia_dejeccions_es.pdf. Accessed on: 29.04 . 2016 .

[33] E. Ghafoori and P. C. Flynn, "Optimizing the logistics of anaerobic digestion of manure," in Applied Biochemistry and Biotechnology: Springer, 2007, pp. 625-637.

[34] T. Pootakham and A. Kumar, "A comparison of pipeline versus truck transport of bio-oil," Bioresource technology, vol. 101, no. 1, pp. 414-421, 2010. 